\title{
Analisis Kesulitan Mahasiswa Dalam Memahami Materi Integral Lipat Dua Pada Koordinat Polar Mata Kuliah Kalkulus Lanjut
}

\author{
Davi Apriandi ${ }^{1}$, Ika Krisdiana ${ }^{2}$ \\ 1,2Prodi Pendidikan Matematika, FPMIPA, IKIP PGRI Madiun: davi_apriandi@yahoo.com
}

\begin{abstract}
This study aims to determine the difficulties experienced by students in understanding the double integral in polar coordinates advanced calculus courses and the factors that cause these problems. This research is qualitative. Subjects were students of the fourth semester of academic year 2015/2016 Mathematics Education, IKIP PGRI Madiun totaling 3 persons. Data collection techniques have used that test, observation, interviews, and documentation. Data analysis technique conducted with qualitative data analysis, namely data reduction, data presentation and conclusion. Technique of data validity using technique triangulation. The results were obtained five kinds of difficulties students in understanding the integral double the coordinates polar, namely 1) the difficulty in drawing a function in polar coordinates and determine the areas of integration, 2) the difficulty in converting the variable into polar coordinates, 3) difficulty in defining the limits of integration, 4) difficulty in writing a form of integration in polar coordinates, 5) difficulties in performing the calculations. Factors causing these difficulties is the ability to understand the matter is low, understanding in drawing a function in two-dimensional and three are still low, difficulties in visualizing the image of a function, do not understand the concept of comparison trigonometry, do not understand in determining the limits of integration in polar coordinates, less rigorous in setting limits of integration, not yet understand the concept of double integral in polar coordinates, lower integration calculation capabilities, yet integral mastered trigonometry.
\end{abstract}

Keywords: learning difficulties; comprehension; calculus; integral double polar coordinates.

\begin{abstract}
Abstrak
Penelitian ini bertujuan untuk mengetahui kesulitan-kesulitan yang dialami mahasiswa dalam memahami materi integral lipat dua pada koordinat polar mata kuliah kalkulus lanjut dan faktor-faktor yang menyebabkan kesulitan tersebut. Penelitian ini merupakan penelitian kualitatif. Subjek penelitian adalah mahasiswa semester IV tahun akademik 2015/2016 Program Studi Pendidikan Matematika, IKIP PGRI Madiun berjumlah 3 orang. Teknik pengumpulan data yang digunakan yaitu tes, observasi, wawancara dan dokumentasi. Teknik analisis data dilakukan dengan analisis data kualitatif, yaitu reduksi data, penyajian data dan penarikan kesimpulan. Teknik keabsahan data menggunakan triangulasi teknik. Hasil penelitian diperoleh 5 jenis kesulitan mahasiswa dalam memahami integral lipat dua pada kordinat polar, yaitu 1) kesulitan dalam menggambar suatu fungsi pada koordinat polar dan menentukan daerah integrasi, 2) kesulitan dalam mengkonversi variabel ke dalam koordinat polar, 3) kesulitan dalam menentukan batas integrasi, 4) kesulitan dalam menuliskan bentuk integrasi dalam koordinat polar, 5) kesulitan dalam melakukan perhitungan. Faktor penyebab kesulitan tersebut adalah kemampuan memahami soal rendah, pemahaman dalam menggambar suatu fungsi di demensi dua dan tiga masih rendah, kesulitan dalam memvisualisasikan gambar suatu fungsi, belum paham konsep perbandingan trigonometri,
\end{abstract}


belum paham dalam menentukan batas integrasi pada koordinat polar, kurang teliti dalam menentukan batas integrasi, belum memahami konsep integral lipat dua pada koordinat polar, kemampuan perhitungan integrasi rendah, belum menguasai integral trigonometri.

Kata Kunci: kesulitan belajar; pemahaman; kalkulus; integral lipat dua koordinat polar.

\section{PENDAHULUAN}

Kalkulus adalah cabang ilmu matematika yang mencakup limit, turunan, integral dan deret takhingga. Kalkulus merupakan ilmu dasar yang perlu dikuasai secara lebih luas dan mendalam oleh para mahasiswa, calon guru, atau calon ilmuwan. Pada program studi Pendidikan Matematika IKIP PGRI Madiun, kalkulus merupakan mata kuliah yang harus ditempuh oleh seluruh mahasiswa pendidikan matematika. Dalam pedoman kurikulum program studi Pendidikan Matematika mata kuliah kalkulus dibagi menjadi kalkulus I, kalkulus II dan kalkulus lanjut. Dilihat dari porsi yang diberikan untuk mata kuliah kalkulus, memang kalkulus merupakan mata kuliah yang sangat penting dan harus dikuasai oleh mahasiswa, karena mata kuliah kalkulus sangat esensial sebagai mata kuliah prasyarat untuk mata kuliah selanjutnya, seperti Persamaan Differensial, Analisis Vektor, Analisis Numerik, Nilai Awal dan Syarat Batas.

Berdasarkan pedoman kurikulum di IKIP PGRI Madiun, mata kuliah kalkulus lanjut mempelajari tentang integral lipat dua atas daerah persegi panjang, integral lipat dua atas daerah umum $\mathrm{R}$, integral lipat dua dalam kordinat polar/kutub, integral lipat tiga dan aplikasi integral lipat tiga. Dari beberapa materi tersebut, salah satu materi yang dianggap sulit bagi mahasiswa adalah integral lipat dua dalam koordinat polar. Hal tersebut, salah satunya dapat dilihat dari rata-rata nilai yang diperoleh mahasiswa pada materi integral lipat dua dalam kordinat polar/kutub, yaitu sebesar 53,37. Rendahnya nilai yang diperoleh mahasiswa salah satunya disebabkan kesulitan mahasiswa dalam memahami materi integral lipat dua dalam koordinat polar. Kesulitan tersebut dapat dilihat dari kesalahan yang sering dilakukan mahasiswa dalam mengerjakan soal-soal integral lipat dua dalam koordinat polar. Sejalan dengan penelitian Kereh bahwa yang bisa dilakukan dalam mengidentifikasi kesulitan belajar mahasiswa dalam konten matematika adalah dengan menganalisis dokumen hasil pengerjaan mahasiswa (Kereh,Sabandar, \& Tjiang, 2013). Rendahnya kemampuan kalkulus mahasiswa pada materi integral lipat dua pada koordinat polar akan berdampak pada kurangnya pemahaman mahasiswa untuk mata kuliah selanjutnya. Pembelajaran yang dilaksanakan pada tahap awal atau dasar harus benar-benar mantap, karena kesulitan belajar yang dialami siswa di tahap awal akan berpengaruh terhadap belajar pada tahap selanjutnya (Widyasari, Meter, \& Negara, 2015).

Menurut Subini dalam (Winiari, Meter, \& Negara, 2015) menyatakan bahwa "pembelajaran merupakan suatu kegiatan yang dilakukan untuk menciptakan keadaan (proses) belajar, oleh karena itu harus dipahami bagaimana siswa mendapatkan pengetahuan dari kegitan belajarnya." Muhibbin Syah dalam (Febriansyah, Yusmin, \& Nursangaji, 2014) juga menyatakan bahwa pembelajaran itu berasal dari kata belajar, belajar yang artinya perubahan tingkah laku.

Praktik pembelajaran yang dilakukan tidak selalu berhasil dikarenakan berbagai hambatan. Hambatan-hambatan tersebut yang membuat kurang optimalnya informasi yang diserap siswa diistilahkan dengan kesulitan belajar (Febriansyah et al., 2014). Pendapat lain 
menyatakan aktivitas belajar bagi setiap individu mahasiswa tidak selamanya dapat berlangsung secara wajar. Terkadang mahasiswa cepat menangkap apa yang dijelaskan dosen terkadang juga terasa sulit, terkadang mudah memahami apa yang dipelajari terkadang juga sulit. Dalam hal semangat terkadang semangat tinggi, tetapi terkadang juga sulit untuk konsentrasi untuk belajar. Dalam hal dimana mahasiswa tidak dapat belajar sebagaimana mestinya, itulah yang disebut dengan kesulitan belajar (Dalyono, 2012).

Kesulitan belajar menjadi suatu kendala yang dialami siswa di Sekolah atau mahasiswa di Perguruan Tinggi. Sehingga kesulitan dalam belajar dapat terjadi pada hampir setiap tahap/jenjang selama masa sekolah anak (Faika \& Side, 2011; Kereh et al., 2013). Merujuk hasil penelitian oleh Nizlel Huda dan Angel Gustina Kencana bahwa kesulitan siswa berdasarkan kemampuan pemahaman dalam menyelesaikan soal cerita pada materi kubus dan balok yang paling dominan yaitu pada penerapan konsep-konsep dalam perhitungan matematis. Terletak pada kesulitan dalam memahami makna dari kata-kata dalam soal, kesulitan dalam mengubah kata-kata dalam soal ke dalam simbol, kesulitan dalam menentukan konsep-konsep yang tepat untuk digunakan, dan kesulitan menggunakan/menerapkan (Huda \& Kencana, 2013). Penelitian oleh Karmawati dengan hasil penelitian bahwa kesulitan yang dialami mahasiswa dalam belajar statistika deskriptif berada pada kategori "Sangat Tinggi" dengan persentase rata-rata sebesar 80,06\% (Karmawati, 2016). Jenis-jenis kesulitan mahasiwa dalam mempelajari materi yang meliputi fakta, konsep, skill dan prinsip. Hasil tingkat jenis-jenis kesulitan di atas, kesulitan yang paling banyak dilakukan oleh mahasiswa adalah kesulitan dalam prinsip (Abidin, 2012; Muhammad \& Kusno, 2015; Rumasoreng \& Sugiman, 2014). Penelitian juga dilakukan dengan hasil mengalami kesulitan belajar matematika yaitu kesulitan mengingat fakta, mengingat konsep, memahami fakta, memahami konsep, menerapkan konsep, menerapkan prosedur, menganalisis prosedural, mengeva-luasi konsep, mengevaluasi prosedur, mengomunikasikan metakognitif dan meneliti fakta serta meneliti prosedur (Kumalasari \& Sugiman, 2015). Siswa yang mengalami masalah atau kesulitan dalam belajar sehingga akan menyebabkan hasil belajar siswa yang rendah (Huda \& Kencana, 2013; Kristinova et al., 2013). Kesulitan yang dialami siswa akan juga berdampak pada ketidaktercapaian kompetetensi dasar yang menjadi acuan pada muatan mata pelajaran (Widyasari et al., 2015).

Secara umum ada dua faktor yang menyebabkan siswa mengalami kesulitan belajar, yaitu faktor internal yaitu berasal dari dalam diri siswa itu sendiri dan faktor eksternal yaitu berasal dari luar diri siswa (Syah, 2012). Faktor internal mencakup minat, motivasi, sikap belajar dan kesehatan fisik maupun kesehatan mental siswa. Sedangkan faktor eksternal antara lain dari lingkungan sekolah, lingkungan keluarga dan lingkungan masyarakat. Faktor dari lingkungan sekolah mencakup dari guru, sarana dan prasarana sekolah. Faktor dari lingkungan keluarga misalnya cara orang tua mendidik anak, hubungan orang tua dan anak, suasana keluarga/rumah dan keadaan ekonomi keluarga. Sedangkan faktor dari lingkungan masyarakat mencakup teman bergaul dan aktivitas atau kesibukan dalam masyarakat serta media massa (Kristinova, Sowinangun, \& Aminuyati, 2013). Mengetahui kesulitan yang dialami mahasiswa, maka dapat dicari faktor-faktor yang menyebabkan kesulitan tersebut.

Banyak penelitian yang telah dilakukan mengenai analisis kesulitan belajar matematika pada siswa yaitu penelitian oleh (Basuki, 2012; Huda \& Kencana, 2013; Pawestri, Soeyono, \& Kurniawati, 2013; Rumasoreng \& Sugiman, 2014). Selain itu beberapa penelitian telah 
dilakukan mengenai analisis kesulitan belajar mahasiswa diantaranya oleh Ade Kumalasari dan Sugiman, penelitian pada mata kuliah Kapita Selekta Matematika (Kumalasari \& Sugiman, 2015), mata kuliah Persamaan differensial (Oktavia \& Khotimah, 2016), kemudian pada mata kuliah statistik (Karmawati, 2016), mata kuliah analisis real (Kartini \& Suanto, 2015), mata kuliah model linear (Muhammad \& Kusno, 2015), mata kuliah geometri (Yuwono, 2016) dan mata kuliah statistik (Rosmiyati \& Afrahamiryano, 2015), pada mata kuliah trigonometri (Abidin, 2012) serta mata kuliah kalkulus 1 (Abidin, 2012; Mutakin, 2015). Keterbaharuan dalam penelitian ini melakukan analisis kesulitan belajar mahasiswa pada mata kuliah kalkulus lanjut khususnya materi integral lipat dua pada koordinat polar.

Berdasarkan uraian yang telah dipaparkan maka penulis tertarik untuk mengetahui analisis kesulitan mahasiswa dalam memahami materi integral lipat dua pada koordinat polar pada mata kuliah kalkulus lanjut, selanjutnya akan dicari penyebab kesulitan tersebut.

\section{METODE PENELITIAN}

Penelitian ini merupakan penelitian kualitatif. Penelitian kualitatif menghasilkan data deskriptif berupa kata-kata tertulis atau lisan dari orang-orang dan perilaku yang dapat diamati. Penelitian ini dilaksanakan pada mahasiswa semester IV tahun akademik 2015/2016 Program Studi Pendidikan Matematika IKIP PGRI Madiun berjumlah 3 orang.

Teknik pengumpulan data dilakukan adalah: 1) Tes, tes yang digunakan dalam penelitian ini adalah tes berbentuk uraian yang diberikan kepada seluruh mahasiswa kelas IVA setelah mahasiswa mendapatkan materi integral lipat dua pada koordinat polar; 2) Observasi, metode observasi dalam penelitian ini digunakan untuk memperoleh informasi mengenai cara mengajar dosen dan cara belajar mahasiswa di kelas yang mungkin menjadi penyebab kesulitan mahasiswa dalam memahami materi integral lipat dua pada koordinat polar, 3) Wawancara, metode wawancara dalam penelitian ini digunakan untuk memperoleh informasi mengenai faktor-faktor penyebab kesulitan mahasiswa dalam memahami materi integral lipat dua pada koordinat polar. Penelitian ini menggunakan wawancara beba yaitu dalam menentukan subjek wawancara yaitu mengambil beberapa mahasiswa yang memiliki nilai tes yang rendah, 4) Dokumentasi, data yang diperoleh dari studi dokumentasi berupa proses pembelajaran kalkulus lanjut materi integral lipat dua pada koordinat polar, hasil tes dan hasil wawancara.

Teknik analisis data yang digunakan dalam penelitian ini adalah analisis data kualitatif meliputi: reduksi data (data reduction), penyajian data (data display dan kesimpulan (drawing/verification). Dalam penelitian ini keabsahan dilakukan dengan triangulasi teknik. Triangulasi teknik dilakukan dengan cara menanyakan hal yang sama dengan teknik yang berbeda, yaitu dengan wawancara dan dokumentasi.

\section{HASIL PENELITIAN DAN PEMBAHASAN}

Observasi terhadap kegiatan pembelajaran dilakukan sebagai salah satu cara untuk mengumpulkan data, yaitu untuk melihat faktor-faktor lain di luar diri mahasiswa yang dapat menyebabkan mahasiswa kesulitan dalam memahami materi integral lipat dua pada koordinat polar mata kuliah kalkulus lanjut. Kegiatan observasi ini dilakukan pada saat dosen mengajarkan materi integral lipat dua pada koordinat polar. Adapun hasil dari observasi yang telah dilakukan adalah sebagai berikut: 


\section{Dosen}

Pada kegiatan awal, Dosen menyampaikan tujuan pembelajaran dan menjelaskan materi pada pertemuan sebelumnya yaitu integral lipat dua pada koordinat kartesius. Dosen menjelaskan bagaimana menggambar bidang-bidang yang diketahui dan menentukan batas integrasi. Dalam pembelajaran dosen menyampaikan materi dengan menggunakan metode ceramah. Materi yang disampaikan adalah integral lipat dua pada koordinat polar. Secara konsep materi ini hampir sama dengan materi sebelumnya hanya batas-batas integrasi harus di konversi pada koordinat polar/kutub. Pertama dosen menjelaskan bagaimana cara mengkonversi variabel $x$ dan y pada koordinat karetesius dirubah menjadi variabel $r$ dan $\theta$ pada koordinat polar. Dengan menggunakan konsep teorema Phytagoras dan perbandingan trigonometri maka diperoleh bahwa $r=\sqrt{x^{2}+y^{2}}, x=r \cos \theta$ dan $y=r \sin \theta$. Kemudian dosen memberikan contoh soal dan dikerjakan bersama mahasiswa. Dalam mengerjakan soal dosen menggambar terlebih dahulu daerah yang ditentukan, kemudian menentukan batas-batas integrasi dan melakukan perhitungan. Setelah selesai menjelaskan, dosen menyuruh mahasiswa untuk memahami apa yang tadi dijelaskan dan menulis di buku masing-masing. Selama mahasiswa menulis, dosen berkeliling untuk mengecek mahasiswa apakah sudah paham atau belum. Setelah itu dosen menyuruh mahasiswa untuk mengerjakan soal yang ada di Buku Kalkulus Lanjut (Verberg, Purcell, Ridgon). Selama mahasiwa mengerjakan, dosen memantau mahasiswa dengan melihat pekerjaan mahasiwa dan memberikan kesempatan mahasiswa untuk bertanya apbila ada soal yang sulit untuk dikerjakan. Selama proses pembelajaran suasana kelas tenang dan teratur.

\section{Mahasiswa}

Selama proses pembelajaran berlangsung, sebagian besar mahasiswa memperhatikan penjelasan dari dosen. Tampak beberapa mahasiswa menunjukan wajah yang bingung terkait dengan materi yang dipelajari. Pada saat dosen menjelaskan materi, hanya beberapa mahasiswa saja yang bertanya, mahasiswa kurang begitu terlibat dalam proses pembelajaran. Hal tersebut berdampak pada saat mahasiswa mengerjakan soal yang diberikan dosen. Banyak siswa yang mengalami kesulitan dalam mengerjakan sehinggga berkali-kali bertanya pada dosen.

Setelah proses pembelajaran, mahasiswa diberikan tes uraian untuk melihat kemampuan mahasiswa dalam pemahaman materi. Adapun soal tes yang diberikan adalah sebagai berikut:

1. Hitung dengan menggunakan koordinat polar $\iint_{S}\left(4-x^{2}-y^{2}\right) d A$, dengan $\mathrm{S}$ daerah pada kuadran pertama dari lingkaran $\mathrm{x}^{2}+\mathrm{y}^{2}=4$ dan diantara $\mathrm{y}=0$ dan $\mathrm{y}=\mathrm{x}$. (buat sketsa daerah integrasi terlebih dahulu)

2. Hitung dengan menggunakan koordinat polar $\iint_{S}\left(x^{2}+y^{2}+9\right) d A$, dengan S daerah pada kuadran pertama dari lingkaran $\mathrm{x}^{2}+\mathrm{y}^{2}=9$ dan diantara $\mathrm{y}=0$ dan $\mathrm{y}=\mathrm{x}$. (buat sketsa daerah integrasi terlebih dahulu)

Setelah mahasiswa mengerjakan tes, diperoleh kesalahan-kesalahan umum yang dilakukan mahasiswa seperti pada tabel 1 berikut.

Tabel 1. Kesalahan dan kesulitan mahasiswa

\begin{tabular}{cc|l}
\hline No. & \multicolumn{1}{c}{ Kesalahan yang terjadi } & \multicolumn{1}{c}{ Kesulitan Mahasiswa } \\
\hline $1 . \quad$ Kesalahan dalam menggambar & $\begin{array}{l}\text { Kesulitan dalam memahami cara } \\
\text { menggambar pada koordinat } \\
\text { polar }\end{array}$ \\
\cline { 2 - 2 } & Kesulitan dalam menggambar \\
\cline { 2 - 2 } & $\begin{array}{l}\text { Kesulitan dalam menentukan } \\
\text { daerah integrasi }\end{array}$ \\
\hline
\end{tabular}




\begin{tabular}{|cll|lr}
\hline No. & \multicolumn{2}{c}{ Kesalahan yang terjadi } & \multicolumn{2}{c}{ Kesulitan Mahasiswa } \\
\hline 2. & $\begin{array}{l}\text { Kesalahan dalam mengkonversi } \\
\text { variabel ke dalam koordinat polar }\end{array}$ & $\begin{array}{l}\text { Kesulitan dalam mengkonversi } \\
\text { variabel ke dalam koordinat polar }\end{array}$ \\
\hline 3. & $\begin{array}{l}\text { Kesalahan dalam menentukan batas } \\
\text { integrasi }\end{array}$ & $\begin{array}{l}\text { Kesulitan dalam menentukan } \\
\text { batas integrasi }\end{array}$ \\
\hline 4. & $\begin{array}{l}\text { Kesalahan dalam menuliskan bentuk } \\
\text { integrasi dalam koordinat polar }\end{array}$ & $\begin{array}{l}\text { Kesulitan dalam menuliskan } \\
\text { bentuk integrasi dalam koordinat } \\
\text { polar }\end{array}$ \\
\hline 5. & $\begin{array}{l}\text { Kesalahan dalam melakukan } \\
\text { perhitungan }\end{array}$ & $\begin{array}{l}\text { Kesulitan dalam } \\
\text { perhitungan }\end{array}$ & melakukan \\
\hline
\end{tabular}

Setelah mahasiswa dikelompokkan berdasarkan kesalahan dan kesulitan dalam menyelesaikan soal, maka dipilih subyek penelitian untuk dianalisis lebih lanjut kesulitannya. Ada 3 subyek penelitian yang diambil dengan jenis kesulitan yang berbeda atau mewakili kesulitan kesulitan yang dialami mahasiswa lain. Berikut adalah hasil analisis tes masing - masing subyek penelitian.

\section{Subjek Penelitian 1}

Berikut adalah hasil pekerjaan mahasiswa, yang menunjukkan dimana letak kesulitan yang dialami beserta faktor penyebabnya.

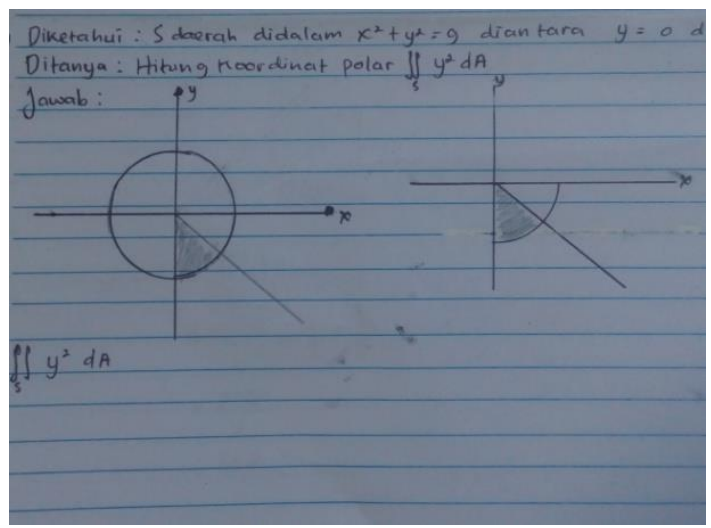

Gambar 1. Hasil pekerjaan subjek 1

Berdasarkan hasil pekerjaan subjek 1 (gambar 1) dan wawancara dapat dideskripsikan kesalahan dan kesulitan yang dilakukan oleh subjek 1 sebagai berikut.

Tabel 2. Hasil Analisis Tes dan Wawancara Subyek Penelitian I

\begin{tabular}{clrllr}
\hline No. & \multicolumn{2}{l}{ Deskripsi Kesalahan } & \multicolumn{2}{l}{ Analisis Wawancara } & \multicolumn{2}{l}{ Kesulitan dari tes } \\
\hline 1. & Salah dalam & - Tidak bisa & Kesulitan dalam \\
& menggambar daerah & membayangkan & memahami cara \\
dari fungsi yang & gambar apa yang akan & menggambar pada \\
diketahui & terbentuk & koordinat polar \\
& & - Kemampuan & \\
& & menggambar subjek 1 & \\
& masih rendah karena & \\
\hline
\end{tabular}




\begin{tabular}{|c|c|c|c|}
\hline No. & Deskripsi Kesalahan & Analisis Wawancara & Kesulitan dari tes \\
\hline & & $\begin{array}{lr}\text { pada } & \text { materi } \\
\text { sebelumnya } & \text { juga } \\
\text { kesulitan } & \text { dalam } \\
\text { menggambar } & \\
\end{array}$ & \\
\hline 2. & $\begin{array}{l}\text { Tidak mengkonversi } \\
\text { variable ke dalam } \\
\text { koordinat polar }\end{array}$ & $\begin{array}{l}\text { Sama sekali tidak paham } \\
\text { apa yang akan dikerjakan }\end{array}$ & $\begin{array}{l}\text { Kesulitan dalam } \\
\text { memahami konversi } \\
\text { variabel ke dalam } \\
\text { kordinat polar }\end{array}$ \\
\hline 3. & $\begin{array}{l}\text { Tidak menuliskan } \\
\text { batas integrasi }\end{array}$ & $\begin{array}{l}\text { Karena dari awal sudah } \\
\text { tidak paham maka untuk } \\
\text { tahapan selanjutnya } \\
\text { tidak dikerjakan }\end{array}$ & $\begin{array}{l}\text { Kesulitan dalam } \\
\text { menentukan batas- } \\
\text { batas integrasi }\end{array}$ \\
\hline 4. & $\begin{array}{lr}\text { Salah } & \text { dalam } \\
\text { menuliskan bentuk } \\
\text { integrasi pada } \\
\text { koordinat polar }\end{array}$ & $\begin{array}{l}\text { Karena dari awal sudah } \\
\text { tidak paham maka untuk } \\
\text { tahapan selanjutnya } \\
\text { tidak dikerjakan }\end{array}$ & $\begin{array}{lr}\text { Kesulitan dalam } \\
\text { menuliskan bentuk } \\
\text { integrasi dalam } \\
\text { koordinat polar }\end{array}$ \\
\hline 5. & $\begin{array}{lr}\text { Tidak melakukan } \\
\text { perhitungan integrasi }\end{array}$ & $\begin{array}{l}\text { Karena dari awal sudah } \\
\text { tidak paham maka untuk } \\
\text { tahapan selanjutnya } \\
\text { tidak dikerjakan }\end{array}$ & $\begin{array}{l}\text { Kesulitan dalam } \\
\text { melakukan } \\
\text { perhitungan integrasi }\end{array}$ \\
\hline
\end{tabular}

Subyek Penelitian I merupakan salah satu mahasiswa yang pasif dalam pembelajaran. Dilihat dari kehadiran/presensi pun termasuk dalam kategori rendah. Sehingga wajar apabila hasil yang diperoleh dari tes kurang memuaskan. Subjek 1 terkadang tidak mengumpulkan tugas yang diberikan oleh dosen. Dari hasil wawancara, subjek 1 merasa kesulitan mengikuti pembelajaran kalkulus lanjut karena untuk matakuliah prasyarat pun juga kurang paham. Sesuai dengan Penelitian yang dilakukan oleh Suci Yuniati, Siyami Intan Kumala Dewi bahwa salah satu faktor penyebab kesuliatan belajar dikarenakan kurang memahami yang berhubungan dengan materi prasyarat (Dewi \& Kusrini, 2014; Yuniati, 2014).

\section{Subjek Penelitian 2}

Berikut adalah hasil pekerjaan mahasiswa, yang menunjukkan dimana letak kesulitan yang dialami beserta faktor penyebabnya.

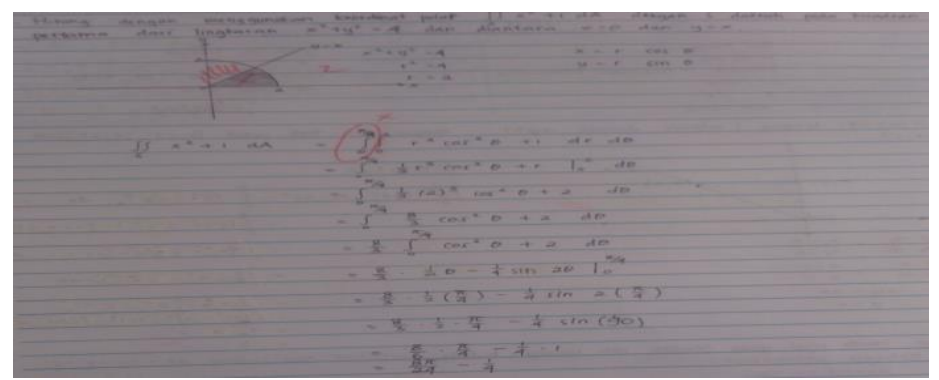

Gambar 2. Hasil pekerjaan subjek 2

Berdasarkan hasil pekerjaan subjek 2 (gambar 2) dan wawancara dapat dideskripsikan kesalahan dan kesulitan yang dilakukan oleh subjek 2 sebagai berikut.

Tabel 3. Hasil Analisis Tes dan Wawancara Subyek Penelitian 2 


\begin{tabular}{|c|c|c|c|}
\hline No. & Deskripsi Kesalahan & Analisis Wawancara & Kesulitan dari tes \\
\hline 1. & $\begin{array}{l}\text { Salah dalam menentukan } \\
\text { daerah integrasi, yang } \\
\text { seharusnya dari } \theta= \\
\frac{\pi}{4} \text { sampai } \theta=\frac{\pi}{2}\end{array}$ & $\begin{array}{l}\text { Soal yang dikerjakan } \\
\text { hampir mirip dengan } \\
\text { soal latihan, sehingga } \\
\text { subjek } 2 \text { tidak } \\
\text { memperhatikan batas } \theta \\
\text { karena menganggap } \\
\text { soal terbut sama dengan } \\
\text { soal latihan. }\end{array}$ & $\begin{array}{lr}\text { Kesulitan } & \text { dalam } \\
\text { menentukan } & \text { daerah } \\
\text { integrasi } & \end{array}$ \\
\hline 2. & $\begin{array}{l}\text { Sudah benar dalam } \\
\text { mengkonversi variable ke } \\
\text { dalam koordinat polar }\end{array}$ & & - \\
\hline 3. & 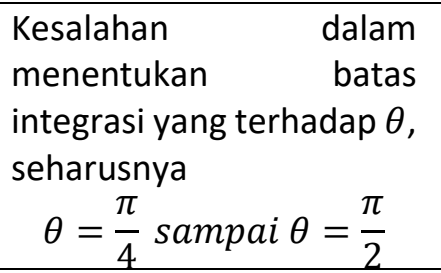 & $\begin{array}{l}\text { Subjek } 2 \text { merasa kurang } \\
\text { teliti karena tidak } \\
\text { memperhatikan batas } \theta\end{array}$ & $\begin{array}{lr}\text { Kesulitan } & \text { dalam } \\
\text { menentukan } & \text { batas } \\
\text { integrasi } & \end{array}$ \\
\hline 4. & $\begin{array}{l}\text { Salah dalam menuliskan } \\
\text { bentuk integrasi pada } \\
\text { koordinat polar }\end{array}$ & $\begin{array}{l}\text { Subjek } 2 \text { lupa bentuk } \\
\text { integrasi pada koordinat } \\
\text { polar } \\
\text { Pemahaman subjek } 2 \\
\text { bahwa } \mathrm{dx} \text { dy diganti } \\
\text { dengan } \mathrm{dr} d \theta\end{array}$ & $\begin{array}{lr}\text { Kesulitan } & \text { dalam } \\
\text { menuliskan bentuk } \\
\text { integrasi dalam } \\
\text { koordinat polar }\end{array}$ \\
\hline 5. & $\begin{array}{l}\text { Sudah benar perhitungan } \\
\text { yang dilakukan tetapi } \\
\text { batas integrasi salah }\end{array}$ & & \\
\hline
\end{tabular}

Subjek penelitian 2 termasuk mahasiswa yang rajin, tertib dan aktif dalam mengikuti perkuliahan. Subjek 2 ini kurang teliti dalam mengerjakan soal-soal. Kurang memahami maksud dari soal. Begitu juga penelitian oleh Suci Yuniati memperoleh hasil bahwa kesulitan dalam menerima informasi terjadinya kesalahan ini dikarenakan mahasiswa tidak teliti dalam membaca soal dan mahasiswa tidak mamahami maksud dari soal (Yuniati, 2014).

\section{Subjek Penelitian 3}

Berikut adalah hasil pekerjaan mahasiswa, yang menunjukkan dimana letak kesulitan yang dialami beserta faktor penyebabnya. 


\section{Gambar 3. Hasil pekerjaan subjek 3}

Berdasarkan hasil pekerjaan subjek 3 (gambar 3) dan wawancara dapat dideskripsikan kesalahan dan kesulitan yang dilakukan oleh subjek 3 sebagai berikut.

Tabel 4. Hasil Analisis Tes dan Wawancara Subyek Penelitian 3

\begin{tabular}{|c|c|c|c|}
\hline No. & Deskripsi Kesalahan & Analisis Wawancara & Kesulitan dari tes \\
\hline 1. & $\begin{array}{l}\text { Salah menentukan } \\
\text { daerah integrasi }\end{array}$ & $\begin{array}{l}\text { Tidak tahu batas } \theta \text { yang } \\
\text { dibatasi oleh } \mathrm{y}=\mathrm{x}\end{array}$ & $\begin{array}{lr}\text { Kesulitan dalam } \\
\text { menentukan } \\
\text { integrasi }\end{array}$ \\
\hline 2. & $\begin{array}{ll}\text { Tidak mengkonversi } \\
\text { variable ke dalam } \\
\text { koordinat polar }\end{array}$ & $\begin{array}{l}\text { Tidak memperhatikan } \\
\text { perintah soal, sehingga } \\
\text { langsung dikerjakan ke } \\
\text { dalam bentuk integrasi } \\
\text { koordinat polar }\end{array}$ & $\begin{array}{l}\text { Kesulitan } \\
\text { mengkonversi } \\
\text { variable ke dalam } \\
\text { koordinat polar }\end{array}$ \\
\hline 3. & $\begin{array}{l}\text { Salah dalam } \\
\text { menentukan batas } \\
\text { integrasi yang terhadap } \\
\theta\end{array}$ & $\begin{array}{l}\text { Karena daerah integrasi } \\
\text { nya salah }\end{array}$ & $\begin{array}{lr}\text { Kesulitan } & \text { dalam } \\
\text { menentukan } & \text { batas } \\
\text { integrasi } & \end{array}$ \\
\hline 4. & $\begin{array}{l}\text { Salah dalam menuliskan } \\
\text { bentuk integrasi pada } \\
\text { koordinat polar }\end{array}$ & $\begin{array}{l}\text { Tidak memperhatikan } \\
\text { perintah soal, sehingga } \\
\text { langsung dikerjakan ke } \\
\text { dalam } \iint r d r d \theta\end{array}$ & $\begin{array}{lr}\text { Kesulitan } & \text { dalam } \\
\text { menuliskan } & \text { bentuk } \\
\text { integrasi dalam } & \text { koordinat polar }\end{array}$ \\
\hline 5. & $\begin{array}{l}\text { Tidak melakukan } \\
\text { perhitungan integrasi }\end{array}$ & $\begin{array}{l}\text { Subjek } 3 \text { merasa tidak } \\
\text { yakin dengan batas } \\
\text { integrasi sehingga } \\
\text { perhitungan tidak } \\
\text { dilanjutkan }\end{array}$ & $\begin{array}{c}\text { Kesulitan melakukan } \\
\text { perhitungan } \\
\text { integrasi }\end{array}$ \\
\hline
\end{tabular}

Subjek penelitian 3 aktif dalam kegiatan mahasiswa di kampus. Terkadang kesibukan di organisasi mahasiswa lebih di utamakan dari pada masuk kuliah. Hal tersebut menyebabkan subjek 3 ketinggalan dalam mengikuti materi yang di ajarkan. Meskipun diluar jam perkuliahan subjek 3 meminta temannya untuk mengajari tetapi subjek 3 sulit untuk memahami materi tersebut. Hasil penelitian ini sejalan dengan penelitian oleh Maria Kristinova dkk dengan kesimpulan bahwa salah satu yang 
mempengaruhi kesulitan belajar merupakan faktor aktivitas atau kesibukan dalam masyarakat, siswa selalu ikut dalam kegiatan/organisasi di luar sekolah (Kristinova et al., 2013). Hasil penelitian ini juga didukung oleh penelitian Erni Untari yang menyimpulkan bahwa kesalahan siswa dalam menyelesaikan soal cerita disebabkan oleh belum memahami konsep, menggunakan proses yang keliru, ceroboh dalam memahami maksud soal, kurang memahami konsep prasyarat, salah dalam komputasi atau perhitungan (Untari, 2013).

\section{SIMPULAN DAN SARAN}

Dari penelitian ini, dapat disimpulkan terdapat 5 jenis kesulitan mahasiswa dalam memahami integral lipat dua pada koordinat polar yaitu : (1) Kesulitan dalam menggambar suatu fungsi pada koordinat polar dan menentukan daerah integrasi. Penyebab kesulitan tersebut adalah pemahaman dalam menggambar suatu fungsi rendah, kemampuan menggambar suatu fungsi di dimensi dua masih rendah, kesulitan dalam memvisualisasikan lebih dari satu fungsi, kemampuan memahami soal rendah, kurang teliti karena masih menganggap soal tersebut seperti contoh soal yang pernah diberikan; (2) Kesulitan dalam mengkonversi variabel ke dalam koordinat polar. Penyebab kesulitan tersebut adalah belum paham konsep perbandingan trigonometri, tidak tahu kalau dalam mengerjakan integrasi harus dikonversi terlebih dahulu; (3)Kesulitan dalam menentukan batas integrasi. Penyebab kesulitan tersebut adalah belum paham dalam menentukan batas integrasi pada koordinat polar, kurang teliti dalam menentukan batas integrase; (4) Kesulitan dalam menuliskan bentuk integrasi dalam koordinat polar. Penyebab kesulitan tersebut adalah belum memahami konsep integral lipat dua pada koordinat polar, belum tahu jika variabel y harus diganti dengan $r \sin \theta$; (5) Kesulitan dalam melakukan perhitungan. Penyebab kesulitan tersebut adalah kemampuan perhitungan integrasi rendah, belum menguasai integral trigonometri.

Berdasarkan kesimpulan penelitian di atas, saran yang dapat disampaikan pada penelitian ini adalah Dosen sebaiknya dalam menyampaikan materi integral lipat dua pada koordinat polar memanfaatkan program komputer seperti Maple untuk membantu mahasiswa dalam memvisualisasikan gambar suatu fungsi, lebih bervariansi dalam memberikan soal latihan, lebih menekankan pemahaman konsep mahasiswa dalam pembelajaran. Mahasiswa agar lebih rajin dan giat dalam belajar, terutama yang berkaiatan dengan integral lipat dua. Bagi peneliti lain, sebaiknya meneliti lebih lanjut kesulitan mahasiswa dan dicari solusi untuk mengatasi kesulitan tersebut.

\section{DAFTAR PUSTAKA}

Abidin, Z. (2012). Analisis Kesalahan Mahasiswa Prodi Pendidikan Matematika Fakultas Tarbiyah IAIN Ar-Raniry Dalam Mata Kuliah Trigonometri dan Kalkulus 1. Jurnal Ilmiah Didaktika, 13(1), 183196.

Basuki, N. R. (2012). Analisis Kesulitan Siswa SMK pada Materi Pokok Geometri dan Alternatif Pemecahannya. Seminar Nasional Pendidikan Matematika Surakarta, 97-104.

Dalyono, M. (2012). Psikologi Pendidikan. Jakarta: Rineka Cipta.

Dewi, S. I. K., \& Kusrini. (2014). Analisis Kesalahan Siswa Kelas VIII Dalam Menyelesaikan Soal pada Materi Faktorisasi Bentuk Aljabar SMP Negeri 1 Kamal Semester Gasal Tahun Ajaran 2013/2014. MATHEdunesa, 3(2), 195-202.

Faika, S., \& Side, S. (2011). Analisis Kesulitan Mahasiswa dalam Perkuliahan dan Praktikum Kimia Dasar di Jurusan Kimia FMIPA Universitas Negeri Makassar. Jurnal Chemica, 12(2), 18-26.

Febriansyah, R., Yusmin, E., \& Nursangaji, A. (2014). Analisis Kesulitan Siswa Dalam Memahami Materi 
Persamaan Linear Dua Variabel di Kelas X SMA. Jurnal Pendidikan Dan Pembelajaran, 3(2), 1-9.

Huda, N., \& Kencana, A. G. (2013). Analisis Kesulitan Siswa Berdasarkan Kemampuan Pemahaman dalam Menyelesaikan Soal Cerita pada Materi Kubus dan Balok Di Kelas VIII SMP Negeri 30 Muaro Jambi. Prosiding Semirata 2013, 1(1), 595-606.

Karmawati. (2016). Analisis Diagnostik Kesulitan Belajar Statistika Mahasiswa BKI Pada Fakultas Ushuluddin Adab dan Dakwah IAIN Palu. ISTIQRA: Jurnal Penelitian IImiah, 4(1), 23-48.

Kartini, \& Suanto, E. (2015). Analisa Kesulitan Pembuktian Matematis Mahasiswa pada Mata Kuliah Analisis Real. Prosiding Semirata, 1(1), 189-199.

Kereh, C. T., Sabandar, J., \& Tjiang, P. C. (2013). Identifikasi Kesulitan Belajar Mahasiswa Dalam Konten Matematika Pada Materi Pendahuluan Fisika Inti. Prosiding Seminar Nasional Sains Dan Pendidikan Sains VIII, Fakultas Sains Dan Matematika, UKSW ISSN:20870922, 4(1).

Kristinova, M., Sowinangun, S., \& Aminuyati. (2013). Analisis Faktor-Faktor Kesulitan Belajar Siswa pada Mata Pelajaran Ips Terpadu Di Kelas VIII A SMP Negeri 3 Sekayam Kabupaten Sanggau. Jurnal Pendidikan Dan Pembelajaran, 2(3), 1-8.

Kumalasari, S., \& Sugiman. (2015). Analisis Kesulitan Belajar Mahasiswa pada Mata Kuliah Kapita Selekta Matematika Sekolah Menengah. Jurnal Riset Pendidikan Matematika, 2(1), 16-27.

Muhammad, M., \& Kusno. (2015). Analisis Diagnostik Kesulitan Belajar Mahasiswa pada Mata Kuliah Model Linier. Khazanah Pendidikan, 9(1), 73-82.

Mutakin, T. Z. (2015). Analisis Kesulitan Belajar Kalkulus 1 Mahasiswa Teknik Informatika. Jurnal Formatif, 3(1), 49-60.

Oktavia, A., \& Khotimah, R. P. (2016). Analisis Kesulitan Mahasiswa Dalam Menyelesaikan Persamaan Differensial Tingkat Satu. Prosiding Koferensi Nasional Penelitian Matematika Dan Pembelajarannya ISSN: 2502-6526, 99-108.

Pawestri, U., Soeyono, \& Kurniawati, I. (2013). Analisis Kesulitan Pembelajaran Maematika Dengan Pengantar Bahasa Inggris Pada Materi Pokok Bentuk Logaritma Kelas X Imersi SMA Negeri Karangpandan Karanganyar 2012/2013. Jurnal Pendidikan Matematika Solusi, 1(1), 1-7.

Rosmiyati, \& Afrahamiryano. (2015). Analisis Kesulitan Mahasiswa Jurusan PMIPA Dalam Pengolahan Data Statistik. Lemma, I(2), 52-56.

Rumasoreng, M. I., \& Sugiman. (2014). Analisis Kesulitan Matematika Siswa SMA/MA Dalam Menyelesaikan Soal Setara UN di Kabupaten Maluku Tengah. Jurnal Riset Pendidikan Matematika, 1(1), 22-34.

Syah, M. (2012). Psikologi Belajar. Jakarta: Rajawali Press.

Untari, E. (2013). Diagnosis Kesulitan Belajar Pokok Bahasan Pecahan Pada Siswa Kelas V Sekolah Dasar. Jurnal IImiah STKIP PGRI Ngawi, 13(1), 1-8.

Widyasari, N. M. D., Meter, I. G., \& Negara, I. G. A. O. (2015). Analisis Kesulitan-Kesulitan Belajar Matematika Siswa Kelas IV Dalam Implementasi Kurikulum 2013 Di SD Piloting Se-Kabupaten Gianyar. MIMBAR PGSD Undiksha, 3(1). 
Winiari, I. G. A., Meter, I. G., \& Negara, I. G. A. O. (2015). Analisis Kesulitan-Kesulitan Belajar Bahasa Indonesia Kelas V Dalam Implementasi Kurikulum 2013 Di SD Piloting Se-Kabupaten Gianyar. Mim, 3(1).

Yuniati, S. (2014). Analisis Kesalahan Mahasiswa Dalam Menyelesaikan Soal Pembuktian pada Matakuliah Struktur Aljabar. Beta: Jurnal Tadris Matematika, 7(2), 72-81.

Yuwono, M. R. (2016). Analisis Kesulitan Mahasiswa Dalam Menyelesaikan Soal Geometri Berdasarkan Taksonomi Bloom dan Alternatif Pemecahannya. Beta: Jurnal Tadris Matematika, 9(2), 111-133. 